Fromberger, M. A., A. J. Campomizzi, Z. M. Lebrun-Southcott, A. L. Pintaric, N. M. MacDonald, and E. Nol. 2020. Factors affecting Bobolink nest survival across grassland types. Avian Conservation and Ecology 15(2):13. https://doi.org/10.5751/ACE-01666-150213

Copyright (C) 2020 by the author(s). Published here under license by the Resilience Alliance.

Research Paper

\title{
Factors affecting Bobolink nest survival across grassland types
}

\author{
Monica A. Fromberger ${ }^{1}$, Andrew J. Campomizzi ${ }^{1,2}$, Zoé M. Lebrun-Southcott ${ }^{2}$, Alice L. Pintaric ${ }^{1}$, Nicole M. MacDonald ${ }^{1}$ and Erica \\ $\mathrm{Nol}^{1}$ \\ ${ }^{1}$ Trent University, ${ }^{2}$ Bird Ecology and Conservation Ontario
}

\begin{abstract}
Grassland birds, including Bobolinks (Dolichonyx oryzivorus), have experienced steep population declines across their breeding range in North America. Because of these declines, Bobolinks were listed as threatened by the Ontario and Canadian governments. We assessed nest survival across land-cover types and uses to identify pertinent factors important for conservation of this species-at-risk. We analyzed nest survival for 463 Bobolink nests monitored over 6 years from 3 regions across southern and eastern Ontario, Canada. We used RMark to analyze daily survival rate of nests by assessing 53 models that incorporated temporal, local, and landscape variables. Daily survival rate of Bobolink nests was strongly associated with cattle (Bos taurus) stocking rate (cattle-days/ ha) and date. Daily survival rate decreased across the nesting season from 0.98 (CI 95\% $=0.97-0.99)$ to $0.92($ CI $95 \%=0.87-0.95)$. Stocking rate was the only important local variable and was negatively associated with daily survival rate, which decreased from 0.96 (CI 95\% $=0.96-0.97)$ to 0.69 (CI 95\% $=0.51-0.82)$ as stocking rate increased from 0 to 243 cattle-days/ha. Landscape variables, including region, percent forest, cropland, and grassland within 2,5 , and $10 \mathrm{~km}$, were not in competitive models. Our results suggest that all field uses we studied have potential for conservation actions because daily survival rate of nests did not vary significantly across late-cut hayfields, fallow fields, restored grasslands, or pastures; however, stocking rate is important in pastures. In grazed pastures where Bobolink conservation is a priority, we recommend keeping stocking rates low ( $\leq 40$ cattle-days/ha) when most Bobolink nests are active, e.g., 21 May (earliest date of incubation) through 30 June (one week after median date of fledging for first nesting attempts) in our study area.
\end{abstract}

\section{Facteurs affectant la survie des nids de goglus des prés entre les différents types de prairie}

RÉSUMÉ. Les oiseaux des prairies, y compris les goglus des prés (Dolichonyx oryzivorus), ont subi de forts déclins de leurs populations sur l'ensemble de leur territoire de reproduction en Amérique du Nord. En raison de cette baisse, le goglu des prés a été répertorié parmi les espèces menacées par les gouvernements de l'Ontario et du Canada. Nous avons évalué la survie des nids sur l'ensemble des types et utilisations de couvertures végétales afin d'identifier les facteurs pertinents importants pour la conservation de cette espèce menacée. Nous avons analysé la survie de 463 nids de goglus des prés placés sous surveillance pendant plus de 6 ans dans 3 régions du sud et de l'est de l'Ontario, au Canada. Nous avons utilisé la méthode RMark pour analyser le taux de survie quotidien des nids en évaluant 53 modèles intégrant des variables temporelles, locales et paysagères. Le taux de survie quotidien des nids de goglus des prés était étroitement lié à la densité d'occupation du bétail (Bos taurus) (journées de pâture par hectare) et à la date. Le taux de survie quotidien a diminué au cours de la saison de nidification, passant de 0,98 (intervalle de confiance de 95\% $=0,97-0,99$ ) à 0,92 (intervalle de confiance de $95 \%=0,87-0,95)$. La densité d'occupation du bétail était la seule variable locale importante et a produit des conséquences négatives sur le taux de survie quotidien, lequel est passé de 0,96 (intervalle de confiance de $95 \%=0,96-0,97$ ) à 0,69 (intervalle de confiance de $95 \%=0,51-0,82$ ) tandis que la densité d'occupation du bétail augmentait de 0 à 243 jours de pâture par hectare. Les variables paysagères, telles que la région, le pourcentage de forestation, le pourcentage de terres cultivées et les prairies dans un rayon de 2,5 et $10 \mathrm{~km}$, n'étaient pas prises en compte dans les modèles compétitifs. Nos résultats suggèrent que toutes les utilisations de terrain que nous avons examinées pourraient donner lieu à des mesures de conservation, car le taux de survie quotidien des nids ne variait pas énormément entre les champs à fauche tardive, les champs en jachère, les prairies restaurées ou les pâturages ; en revanche, la densité d'occupation du bétail est importante dans les pâturages. Dans les pâturages occupés où la conservation du goglu des prés est prioritaire, nous recommandons de maintenir la densité d'occupation du bétail à un niveau faible ( $\leq 40$ jours de pâture par hectare) pendant la période d'activité de la plupart des nids de goglus des prés, c'est-à-dire du 21 mai (la date d'incubation la plus précoce) au 30 juin (une semaine après la date médiane d'envol des oisillons pour la première tentative de nidification) dans notre zone d'étude.

Key Words: farmland birds; grassland birds; landscape ecology; land sharing; range management; restored grassland; RMark; rotational grazing; spatial scale; species at risk

\section{INTRODUCTION}

Grassland birds in North America are experiencing population declines partially driven by loss of breeding habitat and changes in land use (Perlut et al. 2006, Sauer et al. 2013, 2017, Rosenberg et al. 2019). The Bobolink (Dolichonyx oryzivorus) is an obligate grassland bird that breeds across southern Canada and the northern United States (Renfrew et al. 2015). The Bobolink

Address of Correspondent: Monica A. Fromberger, Biology Department, Trent University, 1600 West Bank Drive, Peterborough, Ontario, Canada K9L 0G2, monicafromberger@trentu.ca 
population declined by $76 \%$ in Canada and $80 \%$ in Ontario from 1970 to 2017, based on Breeding Bird Survey data (Smith et al. 2019). Because of these steep declines, the Bobolink is currently listed as threatened by the Ontario and Canadian governments (since 2010 and 2017, respectively; Government of Canada 2017, Government of Ontario 2019). Factors on the breeding grounds that may contribute to this population decline include changes in land use resulting in loss of breeding habitat and changes in management resulting in low fecundity due to incidental nest mortality caused by agriculture operations, including hay harvest and trampling by livestock (Herkert et al. 1996, Herkert 1997, MacDonald and Nol 2017).

Existing research indicates that the nest survival of groundnesting grassland birds can be influenced by a number of different variables. One local variable (within a field and the immediate surrounding area, i.e., $\leq 250 \mathrm{~m}$ of nests) of particular importance is cattle (Bos taurus) stocking rate (i.e., no. cattle $\times$ days a field is grazed/area of the field; Campomizzi et al. 2019). Studies have shown that as the number of cattle and number of days spent grazing increased within a field (i.e., stocking rate increases), nests experienced an increased risk of failure due to trampling (i.e., cattle step or lay on nests; Jensen et al. 1990, Perlut and Strong 2011, MacDonald and Nol 2017, Campomizzi et al. 2019). A reduction in vegetative cover from cattle grazing can also affect the survival of grassland bird nests by increasing the visibility of nests to predators (Paine et al. 1996, Sutter and Ritchison 2005). The grazing system used to manage a pasture, such as rotational grazing, i.e., cattle are moved through multiple fields of subdivided pasture during the grazing season, and continuous grazing, i.e., cattle have access to a pasture for an unrestricted amount of time, can also affect nest survival. Stocking rates are often high in rotationally grazed fields (Jensen et al. 1990); thus, nest survival in these fields has been shown to be lower than in continuously grazed fields (Temple et al. 1999).

Additional variables that have been found to influence nest survival include field use, field area, and distance to forest edge. Studies comparing grassland bird nest survival across field uses have shown that nests are more successful in late-cut hayfields in which harvest is delayed until after nesting, compared to cattle pastures (Perlut et al. 2006, MacDonald and Nol 2017, Pintaric et al. 2019), ungrazed areas compared to grazed pastures (Temple et al. 1999), and restored fields compared to row crops (Patterson and Best 1996). Field use, i.e., pasture and hayfield, was not found to affect the relationship between distance to edge and daily nest survival for Bobolinks (Renfrew et al. 2005, Perkins et al. 2013). Nests monitored in large fields with large core areas had high daily nest survival because edge effects, e.g., enhanced risk of predation, were low (Johnson and Temple 1990, Herkert et al. 2003). Nest survival within $50 \mathrm{~m}$ of forested edges had lower daily survival compared to nests $>100 \mathrm{~m}$ from any edge type, likely due to a higher risk of predation (Bollinger and Gavin 2004). In contrast, both Renfrew et al. (2005) and Perkins et al. (2013) concluded that although Bobolinks nested farther from edges than expected, distance to edge had no detectable effect on nest survival and nest survival did not vary among wooded and nonwooded edge types. Edge effects on nest survival may be difficult to detect because nest losses from predators associated with edges could be masked by the effects of nest losses by predators that are associated with grasslands (Renfrew et al. 2005, Ellison et al. 2013).
Temporal variables, including date and nest age, also influence the daily survival rate of nests. The association between these temporal variables and the daily nest survival rates of grassland birds varies among studies. Some studies have found that nest survival increases throughout the breeding season, possibly related to an increase in vegetation height and protective cover (Lanyon 1957); whereas, others have found a decline in nest survival as the breeding season progresses, possibly due to an increase in predator abundance and movements, i.e., dispersal of individuals, later in the season (Grant et al. 2005). The effect of nest age on nest survival is inconsistent across studies, with some finding lower nest survival during incubation (Winter 1999), some finding lower nest survival during the nestling stage (Davis 2003), and others reporting no difference in nest survival across nest age (Pietz and Granfors 2000). This inconsistent effect of nest age among studies may be caused by differences among species, regions, or predator assemblages (Grant et al. 2005).

The composition of the surrounding landscape can also affect nest survival because landscapes can affect the distribution, abundance, and composition of predators in an area, thus influencing patterns of nest predation (Bergin et al. 2000, Horn et al. 2005, Tewksbury et al. 2006). The association between nest predation and landscape composition is complex and differs across spatial scales (Bergin et al. 2000, Horn et al. 2005, Tewksbury et al. 2006). For example, nest survival was higher for ground-nesting ducks in landscapes with higher amounts of grassland cover within 10 to $41 \mathrm{~km}^{2}$, likely due to differences in predator assemblages (Greenwood et al. 1995, Reynolds et al. 2001, Phillips et al. 2003, Horn et al. 2005). In contrast, studies assessing the effects of landscape composition measured within $200 \mathrm{~m}$ to $16 \mathrm{~km}^{2}$ around grassland songbird nests found no significant association between landscape composition and nest survival (McMaster et al. 2005, Koper and Schmiegelow 2006, Winter et al. 2006). The lack of a consistent landscape effect on nest survival among ground-nesting birds may be explained by differences in the composition of nest predator assemblages and the distance to vegetation where predators are abundant or active, such as forests (Bergin et al. 2000, Pietz and Granfors 2000), and therefore can differ depending on the study area. Because nest predation is one of the leading causes of nest failure for many bird species (Ricklefs 1969, Martin 1993), it is important to assess the effects of landscape composition given the strong influence of the landscape on predator assemblages and the variation in this relationship across studies and spatial scales (Bergin et al. 2000, Horn et al. 2005, Tewksbury et al. 2006).

Despite existing research, knowledge gaps persist regarding how daily survival rates of Bobolink nests vary across land-cover types and uses at different spatial scales, i.e., local and landscape scales (OMNRF 2015, Renfrew et al. 2015). These gaps are important to address given that daily survival rate, i.e., the probability a nest survives one day (Mayfield 1961, Dinsmore et al. 2002), is a useful metric, albeit imperfect (Jones et al. 2005), for informing conservation efforts by identifying areas that are most conducive to successful reproduction. We specifically addressed how daily survival rates of Bobolink nests vary across land-cover types and uses at different spatial scales by collating Bobolink nest monitoring data from previous projects that had various objectives (MacDonald and Nol 2017, Campomizzi et al. 2019, Pintaric et al. 2019) and collecting additional nest data to assess which variables had the greatest influence on daily survival rates. 
We hypothesized that a combination of (1) local, i.e., within a field and $\leq 250 \mathrm{~m}$ of nests, (2) landscape, i.e., region and land cover within 2, 5, and $10 \mathrm{~km}$ of nests, and (3) temporal variables would influence the daily survival rate of Bobolink nests. Specifically, we predicted, based on the existing literature, that stocking rate would have a strong negative effect on the daily survival rate of Bobolink nests; whereas, field area and distance to forest edge would be positively associated with daily survival rates. We also predicted that landscapes with more grassland cover and less forest cover would positively affect daily survival rate of Bobolink nests because landscape composition strongly influences predator assemblages and thus nest predation. Additionally, we predicted that the daily survival rate of Bobolink nests would vary among regions and across the breeding season because of potential differences in predator and prey abundance and vegetation height caused by variation in annual precipitation and differences in land use and management (George et al. 1992, Grant et al. 2005, Pintaric et al. 2019).

\section{METHODS}

\section{Study area}

We included nest monitoring data from three regions of Ontario, Canada, which support medium to high abundances of Bobolinks (Cadman et al. 2007): (1) Renfrew region during 2012, 2013, 2016, and 2017 in late-cut hayfields and cattle pastures that were rotationally grazed, continuously grazed, or ungrazed, (2) Carden region during 2015 and 2016 in late-cut hayfields and continuously grazed cattle pastures (hereafter Carden region), and (3) Dufferin, Grey, Simcoe, and Wellington Counties (hereafter Dufferin region; Fig. 1). These three regions are predominantly rural, consisting of pastures, hayfields, row crops, forests, and wetlands. We monitored nests during the breeding season, May through July, in: (1) Renfrew region during 2012, 2013, 2016, and 2017 in cattle pastures, rotationally grazed, continuously grazed, and ungrazed, and late-cut hayfields, (2) Carden region during 2015 and 2016 in cattle pastures, continuously grazed and late-cut hayfields, and (3) Dufferin region during 2018 in late-cut hayfields, fallow, and restored fields (Table 1). Field use was inconsistent across years and regions; thus, we acknowledge that both year and region are confounded by field use in our study.

We monitored nests in privately owned cattle pastures, in which fields were (1) rotationally grazed, i.e., cattle moved through and grazed $\geq$ three fields of subdivided pasture during the Bobolink breeding season beginning in May to 15 July, (2) continuously grazed, i.e., cattle had unrestricted access to $\geq$ one field[s] throughout the breeding season (OMAFRA 2012), or (3) left ungrazed, i.e., neither cut nor grazed during the breeding season. We also monitored nests in privately owned fallow fields and latecut hayfields, i.e., cut after 15 July (hereafter hayfields), as well as fallow and restored fields in the Luther Marsh Wildlife Management Area in Dufferin region, none of which were grazed. We categorized fields as restored if they were seeded with various native seed mixes for grassland restoration, and fallow if they were not being farmed and had been left to naturalize. All the fallow fields were formerly hay or crop fields and at least four fields had not been farmed for at least eight years. Vegetation in pastures and hayfields was primarily cool-season grasses, i.e.,
Fig. 1. Map of study area in Ontario, Canada, where we monitored 463 Bobolink nests in 3 regions across 6 years: Renfrew (2012, 2013, 2016, 2017), Carden (2015, 2016), and Dufferin (2018).

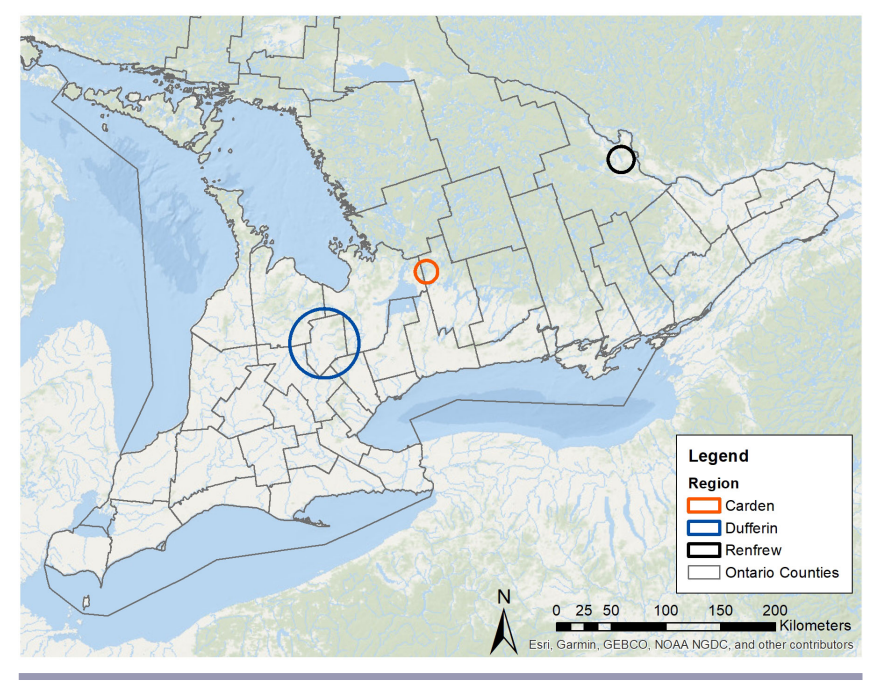

Table 1. Number of Bobolink (Dolichonyx oryzivorus) nests monitored during six years across field types in Renfrew, Carden, and Dufferin regions of Ontario, Canada.

\begin{tabular}{|c|c|c|c|}
\hline Year & Region & Field use, grazing type & No. nests \\
\hline \multirow[t]{3}{*}{2012} & \multirow[t]{3}{*}{ Renfrew } & Pasture, rotational & 7 \\
\hline & & Hayfield & 4 \\
\hline & & Ungrazed & 5 \\
\hline \multirow[t]{3}{*}{2013} & \multirow[t]{3}{*}{ Renfrew } & Pasture, rotational & 12 \\
\hline & & Hayfield & 31 \\
\hline & & Ungrazed & 5 \\
\hline \multirow[t]{2}{*}{2015} & \multirow[t]{2}{*}{ Carden } & Pasture, continuous & 23 \\
\hline & & Hayfield & 10 \\
\hline \multirow[t]{2}{*}{2016} & \multirow[t]{2}{*}{ Carden } & Pasture, continuous & 35 \\
\hline & & Hayfield & 18 \\
\hline \multirow[t]{2}{*}{2016} & \multirow[t]{2}{*}{ Renfrew } & Pasture, rotational & 18 \\
\hline & & Ungrazed & 8 \\
\hline \multirow[t]{4}{*}{2017} & \multirow[t]{4}{*}{ Renfrew } & Pasture, rotational & 53 \\
\hline & & Pasture, continuous & 11 \\
\hline & & Ungrazed & 17 \\
\hline & & Hayfield & 1 \\
\hline \multirow[t]{3}{*}{2018} & \multirow[t]{3}{*}{ Dufferin } & Restored & 102 \\
\hline & & Fallow & 51 \\
\hline & & Hayfield & 52 \\
\hline Total & & & 463 \\
\hline
\end{tabular}

orchard grass (Dactylis glomerata), brome (Bromus spp.), timothy (Phleum pratense) and secondarily, forbs, i.e., alfalfa (Medicago sativa) and clover (Trifolium spp.). Vegetation in restored fields was primarily forbs, i.e., goldenrod (Solidago spp.) and vetch (Vicia spp.) and secondarily, cool-season grasses, i.e., Canada bluegrass (Poa compressa) and redtop (Panicum rigidulum); whereas grass, i.e., Canada bluegrass and redtop, and forb cover, i.e., goldenrod and vetch, were variable among fallow fields. 


\section{Nest monitoring}

We monitored Bobolink nests from mid-May to late July each year. We searched for nests using behavioral cues from adult birds and systematic searching (Martin and Geupel 1993, Winter et al. 2003). We did not approach nests when females were nest building to minimize the risk of abandonment. When we located a nest, we recorded its Global Positioning System (GPS) coordinates, accurate to approximately $3 \mathrm{~m}$, with various handheld devices. We visited nests approximately once every 3 days, on the expected fledge date, i.e., nestling age 11 days, and each subsequent day until young fledged or the nest failed. We documented the nest contents, e.g., number of eggs or young and condition of nest or young, and adult behavior on each visit.

When we found an inactive nest, we used adult behavior, age of nestlings on the previous nest check, and condition of the nest to determine the fate of the nest, i.e., fledged, trampled, depredated, or other, e.g., abandoned. We considered nests fledged when nestlings were near fledging age on the previous visit and we observed adults (1) carrying food to multiple locations near (<40 m) the nest; (2) alarm calling constantly; (3) repeatedly flying $\leq 5 \mathrm{~m}$ of us; (4) flicking their wings and tail when we entered their territory; or (5) attempting to lead us away from the nest location. In addition to adult behavior, we visited the nest to record further evidence of fledging, e.g., an empty nest cup, condition of the nest, feces left from fledglings (Renfrew et al. 2005). We considered a nest to be trampled if we found evidence of cattle movements around the nest location, i.e., flattened or chewed vegetation, and either saw a flattened nest or did not observe the adult birds tending to the nest if we were unable to relocate the nest. It is possible that some nests may have been depredated first and then trampled, in which case the frequency of failure caused by trampling could be overestimated. We considered a nest depredated if we found an empty nest after the nest contained eggs or nestlings on the previous visit and we did not observe evidence of fledged young. We considered a nest failed for other reasons, including death by natural causes or abandonment, if we found dead young or cold eggs in the nest and no adult birds tending the nest on more than one visit.

We determined nest initiation date, i.e., first-egg date, by backdating from known or estimated hatch date, age of nestlings, or fledge date, assuming one egg was laid per day, incubation occurred for 12 days, and nestlings developed in the nest for 11 days before fledging (Martin 1974, Renfrew et al. 2015).

\section{Local variables}

We examined the following local variables for inclusion in analyses: (1) field use, (2) field area, (3) stocking rate, (4) distance to forest edge, and (5) percent land-cover types within a $250 \mathrm{~m}$ buffer of each nest (Table 2).

We documented field use as hayfield, fallow, restored, rotationally grazed pasture, continuously grazed pasture, or ungrazed pasture, for each year and field in which Bobolink nests were found. We calculated field area (ha) using ArcGIS (ESRI 2018, ArcGIS Desktop, version 10.6.1) and ground truthed GPS coordinates at field corners and edges. A field was defined as the area within edges including fence lines, hedge rows, roadways, tree lines, or a combination of these.
Table 2. Summary statistics for all predictor variables included in nest survival models collated for 463 Bobolink (Dolichonyx oryzivorus) nests monitored in Ontario, Canada. Percent landscape composition variables based on annual crop inventory data (Agriculture and Agri-Food Canada 2018, 2019a).

\begin{tabular}{|c|c|c|c|c|}
\hline Variable & Mean & Median & Min. & Max. \\
\hline Field area (ha) & 16.0 & 9.3 & 1.4 & 161.8 \\
\hline Stocking rate (cattle-days/ha) ${ }^{\dagger}$ & 12.5 & 0.0 & 0.0 & 243.1 \\
\hline Distance to forest edge (m) & 176.8 & 150.9 & 4.0 & 929.6 \\
\hline$\%$ grassland $250^{*}$ & 68.6 & 74.0 & 4.2 & 100.0 \\
\hline$\%$ cropland $250^{*}$ & 7.9 & 2.7 & 0.0 & 48.1 \\
\hline$\%$ forest $250^{\star}$ & 6.8 & 3.1 & 0.0 & 52.4 \\
\hline$\%$ shrubland $250^{*}$ & 4.5 & 2.3 & 0.0 & 78.5 \\
\hline$\%$ water $250^{\star}$ & 1.8 & 0.0 & 0.0 & 39.4 \\
\hline$\%$ grassland $2^{\S}$ & 32.1 & 27.3 & 8.7 & 67.5 \\
\hline$\%$ cropland $2^{\S}$ & 20.9 & 16.8 & 0.0 & 61.4 \\
\hline$\%$ forest $2^{\S}$ & 20.8 & 19.3 & 4.2 & 54.2 \\
\hline$\%$ forest $5^{1}$ & 22.2 & 21.1 & 10.0 & 46.4 \\
\hline$\%$ grassland 10 & 22.6 & 21.9 & 9.7 & 57.1 \\
\hline
\end{tabular}

Number of cattle $\mathrm{x}$ days grazed/area grazed.

\$ithin a $250 \mathrm{~m}$ buffer around each nest.

${ }^{\S}$ Within a $2 \mathrm{~km}$ buffer around each nest.

${ }^{1}$ Within a $5 \mathrm{~km}$ buffer around each nest.

"Within a $10 \mathrm{~km}$ buffer around each nest.

We calculated peak-season stocking rate (hereafter, stocking rate; cattle-days/ha) for each grazed pasture as the product of the number of cattle and the number of days each field was grazed from the earliest date of incubation (21 May) through the median date of fledging (23 June) of suspected first nesting attempts, i.e., when most nests were active during our study, divided by the area of the field (ha). We used these dates to calculate the stocking rate because Campomizzi et al. (2019) found this metric was a better predictor of the probability of young Bobolinks fledging from territories compared to the stocking rate across the entire breeding season. Although various metrics for stocking rate occur in the literature, this calculation provides a number that increases with an increasing number of cattle and days of grazing, and decreases with increasing area grazed (Guthery and Bingham 1996). We were interested in the impact of grazing cattle on Bobolinks, not the amount of forage required for cattle. Therefore, we counted cow-calf pairs as 1.5 cattle because we suspected that grazing, trampling, and laying by a calf would be equal to about half the impacts of a cow (Campomizzi et al. 2019). For rotationally grazed pastures grazed on multiple occasions during 21 May-23 June, we summed the stocking rate across these occasions for each pasture to account for the increased grazing pressure. If the number of cattle changed during 21 May-23 June, we summed the corresponding stocking rates to account for the change in grazing pressure. The mean stocking rate was 63.6 cattle-days/ha (range $=0-243.1, n=37$ pastures) in rotationally grazed pasture, and 20.2 cattle-days/ha (range $=0-57.4, n=24$ pastures) in continuously grazed pasture.

We calculated distance to forest edge $(m)$ using the Near tool in ArcGIS and the Ontario Annual Crop Inventory (ACI) raster layer (AAFC 2018, 2019a) corresponding to the year each nest was active. The ACI consistently delivers a land-cover raster that 
meets the overall target accuracy of at least $85 \%$ at a resolution of $30 \mathrm{~m}$ (AAFC 2019b). We defined forest using the ACI guidelines, as predominantly treed areas and we combined the four ACI forest-cover types including coniferous, broadleaf, mixed wood, and undifferentiated (AAFC 2019b) into one forestcover type. Forest edge was defined as the transition from forest cover to another land-cover type (e.g., pasture and forage).

We estimated the percent of land-cover types (e.g., forest, cropland, and grassland) at the local scale of a $250 \mathrm{~m}$ buffer around each nest. We assumed that a buffer distance of $250 \mathrm{~m}$ would be representative of the effects of local habitat composition because it includes the area in the immediate vicinity of the nest and it is substantially smaller than the scale of landscape variables we wanted to investigate (i.e., 2, 5, and $10 \mathrm{~km}$ ). We defined landcover types using ACI definitions (AAFC 2019b). Cropland included a combination of all crop types listed by the ACI, defined as agricultural land including annual and perennial crops. Pasture and forage included tame grasses and other perennial crops such as alfalfa and clover grown alone or mixtures for hay, pasture, or seed. Grassland included predominantly native grasses and other herbaceous vegetation, as well as some shrubland. Because there were only small percentages of grassland identified by the ACI surrounding nests we monitored (mean at $2 \mathrm{~km}=3 \%, 5 \mathrm{~km}=2 \%$, $10 \mathrm{~km}=2 \%$ ), we combined grassland with pasture and forage into one cover type, which we refer to hereafter as grassland.

We tested for collinearity among local variables using Pearson's correlation coefficient $(r)$. If variables were strongly correlated (| $r \mid \geq 0.60$; Evans 1996), they were not included in the same model to avoid multicollinearity. Ultimately, we included the local variables: stocking rate, field use, field area, distance to forest edge, and percent grassland, forest, cropland, shrubland, and water within a $250 \mathrm{~m}$ buffer around each nest.

\section{Landscape variables}

We examined percent land-cover types at three scales, 2, 5, and $10 \mathrm{~km}$ buffers around each nest (Appendix 1, Table A1.1). We calculated land-cover percentages for each nest using the Tabulate Intersect tool in ArcGIS and the corresponding ACI layer for the year each nest was active. Landscape variables varied among nests, years, and regions (see Table 3 for regional variation). We determined regional landscape composition by averaging percent land-cover types within a $10 \mathrm{~km}$ buffer of each nest across years when nest monitoring occurred within each region; Carden $(n=$ 86 nests; 2015, 2016), Dufferin ( $n=205$ nests; 2018), and Renfrew ( $n=172$ nests; 2012, 2013, 2016, 2017; Table 3). We assessed landcover types with $>5 \%$ average cover around each nest $(n=463$ nests; Appendix 1, Table A1.1).

We tested for collinearity among landscape variables using Pearson's correlation coefficient $(r)$. If variables were strongly correlated $(|r| \geq 0.60$; Evans 1996) they were not included in the same model to avoid multicollinearity. Many strong correlations existed for land-cover types across the 3 buffer distances (e.g., cropland at $10 \mathrm{~km}$ was highly correlated with cropland at 5 and $2 \mathrm{~km}$; Appendix 1, Table A1.2). We considered correlations among all land-cover types and decided which variables to include to maximize the number of land-cover types and buffer distances in models. Ultimately, we included the landscape variables: cropland $(2 \mathrm{~km})$, forest (2 and $5 \mathrm{~km})$, and grassland (2 and $10 \mathrm{~km})$ in the nest survival analysis because these were not correlated and had average percent cover around each nest $>20 \%$ (Table 2; Appendix 1, Table A1.2).

Table 3. Landscape composition, based on Annual Crop Inventory data (Agriculture and Agri-Food Canada), within each study region in Ontario, Canada. Percent composition within a $10 \mathrm{~km}$ buffer surrounding each nest was averaged across years when nest monitoring occurred within each region; Carden $(\mathrm{n}=$ 86 nests; 2015, 2016), Dufferin ( $\mathrm{n}=205$ nests; 2018), and Renfrew ( $n=172$ nests; 2012, 2013, 2016, 2017). Other includes: shrub, exposed, fallow, and urban land.

\begin{tabular}{lcccccc}
\hline \hline & \multicolumn{5}{c}{$\%$ land cover } \\
\cline { 2 - 7 } Region & Cropland & Forest & Grassland & Water & Wetland & Other \\
\hline Carden & 2 & 28 & 17 & 6 & 30 & 17 \\
Dufferin & 45 & 16 & 23 & 3 & 5 & 7 \\
Renfrew & 13 & 42 & 25 & 9 & 1 & 10 \\
\hline
\end{tabular}

\section{Nest survival analyses}

We calculated daily survival rate (Mayfield 1961, Dinsmore et al. 2002) using the RMark package (Laake 2013) in R (version 3.5.1; $\mathrm{R}$ Core Team 2016). The nest survival model in this package enabled us to calculate estimates of the daily survival rate of nests and incorporate predictor variables using a logit-link function (Walker et al. 2013). We excluded nests when any of the following information was unknown or could not be calculated: (1) the day the nest was found, (2) the last day the nest was active and contained eggs or young, (3) the last day the nest was checked, or (4) fate of the nest: fledged or failed. We translated ordinal dates into Bobolink-specific dates (hereafter referred to as date) in which the first initiation date was 0 (18 May, ordinal day 138) and the final nest check date was 65 (22 July, ordinal day 203).

Similar to Dinsmore and Dinsmore's (2007) nest survival analysis, we employed a hierarchical-modeling approach because it enabled us to run fewer models at one time and guided our analysis to better understand the additive effects of temporal, local, and landscape variables. Our model building occurred in three stages.

We first assessed the effect of nest age (i.e., age of nest in days, where age $0=$ day first egg laid) on the daily survival rate of nests $(n=400)$ because this predictor variable limited sample size. We ran seven candidate models (including an intercept-only model) consisting of the temporal variables: nest age, date, quadratic date, cubic date, and year and found that nest age was not an important predictor variable of daily survival rate because it was neither in the top model nor a competitive model (i.e., $\triangle \mathrm{AICc}<7$; Burnham et al. 2011). Therefore, we removed nest age from the analysis, enabling us to incorporate an additional 63 nests where nest age could not be calculated, i.e., found during incubation but failed before hatching, therefore unable to determine day first egg laid. We also assessed the effect of year on the daily survival rate of nests because region and year were confounded in our study and, as RMark cannot currently run mixed models, we could not include year as a random effect (Rotella et al. 2004, Rotella 2007, Guilherme et al. 2018). To assess the effect of year, we analyzed data across years for regions and field uses where year was replicated. We ran five models (including an intercept-only model) 
consisting of year and field use, as well as an additive and interaction model for nests found in Carden $(2015,2016)$ and Renfrew $(2012,2013,2016,2017)$ regions separately. We found that year was not an important predictor variable of daily survival rate because only field use occurred in the top model for both regions and when year occurred in a competitive model for Carden region, the $95 \%$ confidence interval of year overlapped zero (Arnold 2010). Therefore, we removed year from the analysis and included region in our candidate models.

In the second stage of modeling, we assessed a candidate set of four temporal models (including an intercept-only model) consisting of the variables: date, quadratic date, and cubic date. Finally, in the third stage of modeling, we carried the top model from stage two as a foundation for building our candidate set of 52 spatial (i.e., local and landscape) models, giving us a total of 53 models including the top model (null model) from stage two (Appendix 1, Table A1.3). We used Akaike's Information Criterion (Akaike 1973), adjusted for small sample size (AICc; Hurvich and Tsai 1989) because this is the default model selection criteria RMark uses for nest survival models to assess relative model fit. We considered models with $\triangle \mathrm{AICc}<2$ to have substantial support (Burnham and Anderson 2002) and considered models with a $\triangle \mathrm{AICc}$ range of 2-7 to have some support (Burnham et al. 2011). Only variables with 95\% confidence intervals not overlapping zero were considered important for explaining daily survival rate (Arnold 2010). There is currently no goodness-of-fit test for nest survival models in RMark (Dinsmore and Dinsmore 2007, Laake and Rexstad 2008, Rotella 2009).

\section{RESULTS}

We monitored 463 Bobolink nests across cattle pastures (rotationally grazed, continuously grazed, or ungrazed), late-cut hayfields, fallow fields, and restored fields (Table 1). The most common cause of nest failure was predation, accounting for $79 \%$ of nest failures, followed by trampling (17\%), and abandonment (4\%, $n=193$; Table 4). Nest failure varied by field use. Trampling was the most common reason for nest failure in rotationally grazed pastures (accounting for 53\% of nest failures, $n=53$; Table 4 ); whereas predation was the most common reason for nest failure across the other field uses ( $92 \%$ of nest failures, i.e., 129 of 140). Landscape composition varied by region. Dufferin region had the highest percentage of cropland $(45 \%)$ compared to Renfrew (13\%) and Carden ( $2 \%$ ) regions. Renfrew region had the highest percentage of forest $(42 \%)$ and grassland cover $(25 \%)$ compared to Dufferin $(16 \%, 23 \%)$ and Carden $(28 \%, 17 \%)$ regions, respectively (Table 3 ).

\section{Nest survival analyses}

After removing nest age and year in the first stage of modeling, the top model from the second stage of modeling temporal variables was date ${ }^{2}$ (Table 5). However, because the $95 \%$ confidence interval for date ${ }^{2}$ overlapped zero, date, which occurred in the second-best supported model, was the only important variable identified in stage two (Table 6; Arnold 2010). Additionally, the relative variable importance, i.e., sum of the Akaike weights across all models in the set where the variable occurs (Burnham and Anderson 2002), of date (i.e., 0.98) was higher than date ${ }^{2}$ (i.e., 0.59), suggesting that date was more important relative to the other variables in stage two of modeling
(Table 5). In the third stage of modeling, after adding local and landscape variables to the top model from stage two (i.e., date), the final top model explaining daily survival rate of Bobolink nests was: date + stocking rate (Table 7 , Table 8).

Table 4. Causes of Bobolink (Dolichonyx oryzivorus) nest failure for each field use monitored in Ontario, Canada.

\begin{tabular}{lccc}
\hline \hline Field use (no. failed nests) & $\begin{array}{c}\% \\
\text { depredated }\end{array}$ & $\begin{array}{c}\% \\
\text { trampled }\end{array}$ & $\begin{array}{c}\% \\
\text { abandoned }\end{array}$ \\
\hline Rotationally grazed pasture $(n=53)$ & 43 & 53 & 4 \\
Continuously grazed pasture $(n=$ & 87.5 & 10 & 2.5 \\
$40)$ & & & \\
Fallow field $(n=14)$ & 93 & 7 & 0 \\
Ungrazed pasture $(n=13)$ & 92 & 0 & 8 \\
Restored grassland $(n=35)$ & 94 & 0 & 6 \\
Hayfield $(n=38)$ & 95 & 0 & 5 \\
Total $(n=193)$ & 79 & 17 & 4 \\
\hline
\end{tabular}

Table 5. Model selection results for stage two of analysis of daily survival rate of Bobolink (Dolichonyx oryzivorus) nests explained by temporal covariates ranked by Akaike's Information Criterion corrected for small sample size (AICc) for 463 nests.

\begin{tabular}{lcccc}
\hline \hline Nest survival models & $\mathrm{K}^{\dagger}$ & $\Delta \mathrm{AICc}^{*}$ & $\begin{array}{c}\text { AICc } \\
\text { weight }\end{array}$ & Dev $^{\S}$ \\
\hline${\text { Date }+ \text { Date }^{2} *}_{\text {Date }}^{3}$ & 3 & 0.00 & 0.43 & 1147.92 \\
Date + Date $^{2}+$ Date $^{3}$ & 2 & 0.19 & 0.39 & 1150.11 \\
Intercept $^{*}$ & 4 & 2.00 & 0.16 & 1147.92 \\
\hline
\end{tabular}

${ }^{\dagger}$ Number of parameters in the model.

\$Difference in AICc values compared to the best-supported model. AICc

$=1153.92$ for the best supported model.

${ }^{\S}$ Model deviance.

* Indicates best-supported model.

Table 6. Model parameter estimates and 95\% confidence interval $(95 \%$ CI) for the top two models from the second stage of modeling the daily survival rate of Bobolink (Dolichonyx oryzivorus) nests explained by temporal covariates.

\begin{tabular}{llcc}
\hline \hline Model & Variable & Estimate & $95 \%$ CI \\
\hline Date + Date $^{2}$ & Intercept & 4.5777 & $3.3536,5.8018$ \\
& Date & -0.0740 & $-0.1487,0.0007$ \\
& Date $^{2}$ & 0.0008 & $-0.0003,0.0018$ \\
Date & Intercept $^{*}$ & 3.7473 & $3.3129,4.1816$ \\
& Date $^{*}$ & -0.0201 & $-0.0333,-0.0070$ \\
\hline
\end{tabular}

* Indicates important predictor variable.

Predicted daily survival rate of Bobolink nests decreased from 0.98 (CI 95\% $=0.97-0.99)$ to 0.92 (CI 95\% $=0.87-0.95$ ) across date of the breeding season, while holding the other covariate of the top model at its mean (stocking rate $=12.54$ cattle-days $/$ ha; Fig. 2). Daily survival rate was also negatively associated with stocking rate, decreasing from 0.96 (CI 95\% $=0.96-0.97)$ when stocking rate was 0 to $0.69(\mathrm{CI} 95 \%=0.51-0.82)$ at the maximum stocking rate of 243 cattle-days/ha, while holding date at its mean (date $=33$; Fig. 3). 
Table 7. Model selection results for stage three of analysis of daily survival rate of Bobolink (Dolichonyx oryzivorus) nests in Ontario, Canada explained by local, landscape, and temporal covariates ranked by Akaike's Information Criterion corrected for small sample size (AICc) for 463 nests. The table includes candidate models where $\triangle \mathrm{AICc}<7$.

\begin{tabular}{|c|c|c|c|c|}
\hline Nest survival models & $\mathrm{K}^{\dagger}$ & $\Delta \mathrm{AICc}^{\dagger}$ & $\begin{array}{c}\text { AICc } \\
\text { weight }\end{array}$ & $\mathrm{Dev}^{\S}$ \\
\hline 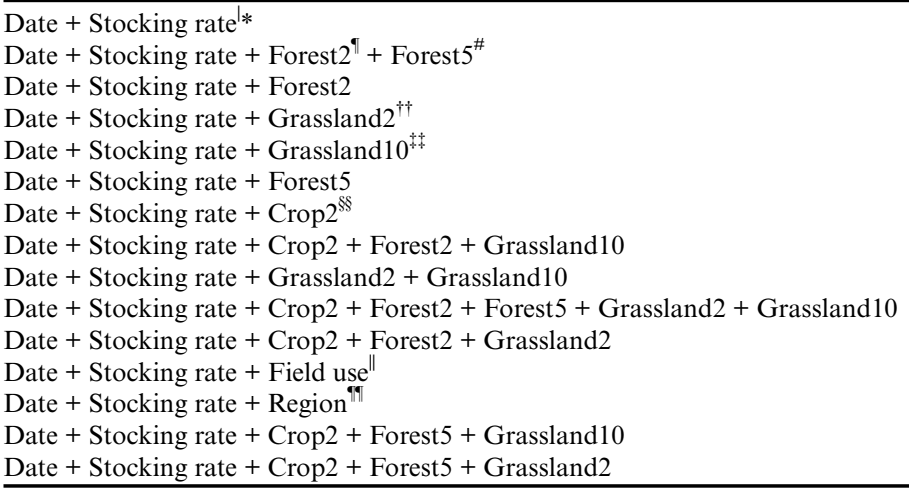 & $\begin{array}{l}3 \\
5 \\
4 \\
4 \\
4 \\
4 \\
4 \\
6 \\
5 \\
8 \\
6 \\
8 \\
6 \\
6 \\
6 \\
6\end{array}$ & $\begin{array}{l}0.00 \\
0.02 \\
0.33 \\
0.85 \\
1.17 \\
1.28 \\
1.97 \\
2.16 \\
2.35 \\
3.50 \\
3.54 \\
3.76 \\
4.13 \\
4.51 \\
4.64 \\
\end{array}$ & $\begin{array}{l}0.16 \\
0.15 \\
0.13 \\
0.10 \\
0.09 \\
0.08 \\
0.06 \\
0.05 \\
0.05 \\
0.03 \\
0.03 \\
0.02 \\
0.02 \\
0.02 \\
0.02 \\
\end{array}$ & $\begin{array}{l}1120.54 \\
1116.55 \\
1118.87 \\
1119.39 \\
1119.71 \\
1119.81 \\
1120.51 \\
1116.68 \\
1118.88 \\
1114.01 \\
1118.06 \\
1114.28 \\
1118.66 \\
1119.04 \\
1119.16 \\
\end{array}$ \\
\hline \multicolumn{5}{|c|}{$\begin{array}{l}\text { Number of parameters in the model. } \\
\text { Difference in AICc values compared to the best-supported model. AICc }=1126.55 \text { for the best supported model. } \\
\text { Model deviance. } \\
\text { 'Number cattle } \times \text { days grazed/area grazed. } \\
\text { \% \% forest within } 2 \mathrm{~km} \text { buffer around each nest. } \\
\# \% \text { forest within } 5 \mathrm{~km} \text { buffer around each nest. } \\
\$ \% \text { pasture, forage, and grassland within } 2 \mathrm{~km} \text { buffer around each nest. } \\
+\% \text { pasture, forage, and grassland within } 10 \mathrm{~km} \text { buffer around each nest. } \\
\$ \$ \text { crop within } 2 \mathrm{~km} \text { buffer around each nest. } \\
\text { grazed pasture (rotational and continuous), ungrazed pasture, hayfield, fallow field, restored grassland. } \\
\text { * Carden, Dufferin, and Renfrew regions. } \\
\text { * Indicates best-supported model. }\end{array}$} \\
\hline
\end{tabular}

Table 8. Top model parameter estimates and $95 \%$ confidence interval $(95 \% \mathrm{CI})$ from the third stage of modeling the daily survival rate of Bobolink (Dolichonyx oryzivorus) nests explained by local, landscape, and temporal covariates.

\begin{tabular}{lcc}
\hline \hline Variable & Estimate & $95 \%$ CI \\
\hline Intercept & 3.993 & $3.540,4.446$ \\
Date* $_{\text {Stocking Rate }}^{\dagger *}$ & -0.023 & $-0.036,-0.010$ \\
\hline
\end{tabular}

${ }^{\dagger}$ Number cattle $\times$ days grazed/area grazed.

* Indicates important predictor variables.

Although models including landscape variables, such as percent forest cover within a $2 \mathrm{~km}$ buffer, had $\Delta \mathrm{AICc}<2$, they were not considered competitive with the top model because they included $\geq 1$ additional variable (i.e., not upholding the principle of parsimony) and the $95 \%$ confidence intervals for these landscape variables overlapped 0 (Table 7; Burnham and Anderson 2002, Arnold 2010). Region and local predictor variables including field use, field area, distance to forest edge, and land-cover types within $250 \mathrm{~m}$ were not in competitive models (Table 7, Appendix 1, A1.3).

\section{DISCUSSION}

Our results identified one temporal variable, date, and one local variable, cattle stocking rate, as the only important predictors of
Fig. 2. Estimated daily survival rate of Bobolink (Dolichonyx oryzivorus) nests across date in Ontario, Canada. Date $0=18$ May, date $35=22$ June, and date $65=22$ July ( $n=463$ nests). We held the other covariate of the top model: date + stocking rate at its mean (stocking rate $=12.54$ cattle-days $/$ ha). Shaded areas indicate $95 \% \mathrm{CI}$.

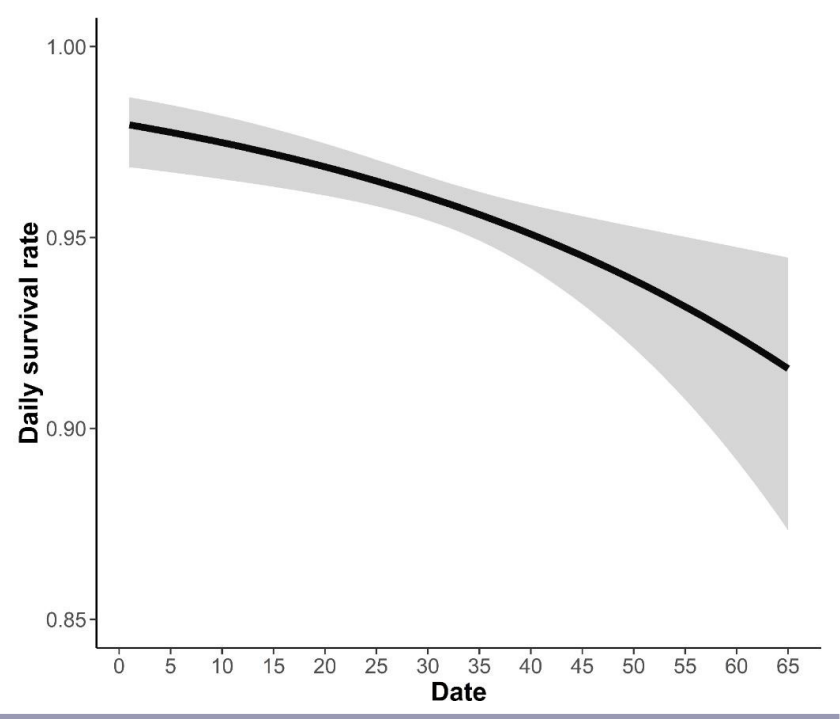


Fig. 3. Estimated daily survival rate of Bobolink (Dolichonyx oryzivorus) nests across observed stocking rate 0-243 cattledays/ha in Ontario, Canada $(n=463$ nests $)$. We held the other covariate of the top model: date + stocking rate at its mean $($ date $=33)$. Shaded areas indicate $95 \%$ CI.

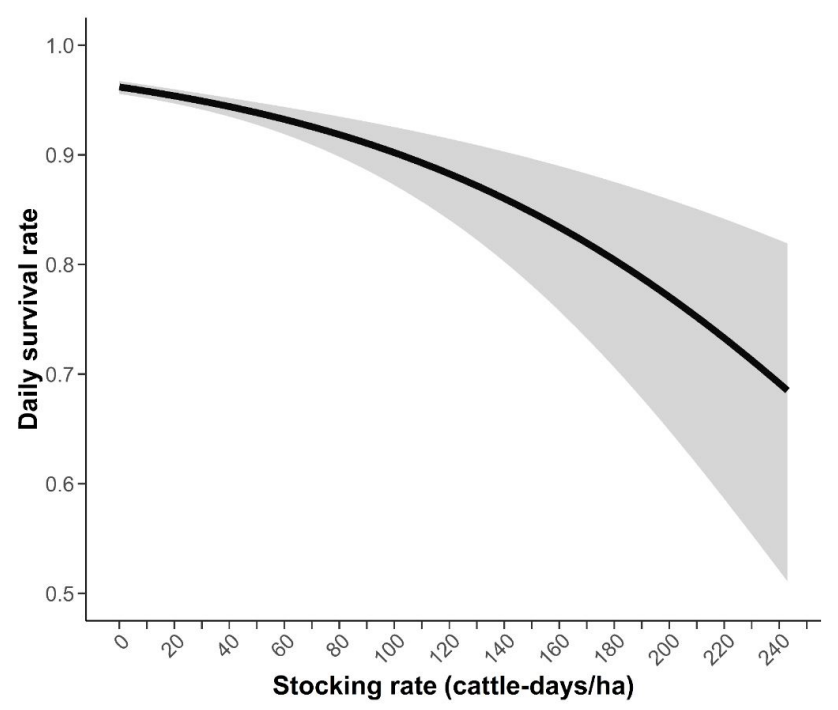

the daily survival rate of Bobolink nests across three regions spread throughout much of the species' Ontario breeding range. Daily survival rate decreased across the breeding season and was negatively associated with stocking rate. Interestingly, we did not find evidence of daily survival rate varying with field use (although dependant on stocking rate in grazed pastures), field area, distance to forest edge, or landscape composition. These results suggest that Bobolinks can breed successfully under many conditions, and that only a few variables (e.g., cattle stocking rate, hay harvesting) may need to be managed to provide nesting habitat conducive to high daily survival rate of nests.

The daily survival rate of Bobolink nests was negatively associated with cattle stocking rate in our study, a result that confirms the findings of many other studies (Perlut and Strong 2011, MacDonald and Nol 2017, Campomizzi et al.2019). This negative association may be because of direct (trampling) or indirect (grazing of vegetation cover) effects of cattle, or both (Paine et al. 1996, Sutter and Ritchison 2005, Perlut and Strong 2011, MacDonald and Nol 2017). Previous research on the indirect effects of cattle grazing on grassland bird nest survival has shown that shorter and less dense vegetation in grazed pastures can enable predators to move more easily throughout a pasture compared to tall, dense vegetation in ungrazed areas (Johnson and Temple 1990, Sutter and Richison 2005). This ease of movement coupled with the increased ability of a predator to observe parental activity and nest locations in shorter vegetation may enable greater instances of nest predation to occur in grazed pastures compared to ungrazed areas (Sutter and Richison 2005). Studies investigating the direct effects of cattle grazing on nest survival have found that the percent of nests trampled increases as cattle density increases and that the potential for nest trampling increases exponentially with the length of time cattle remain in a field (Jensen et al. 1990, Perlut and Strong 2011, MacDonald and Nol 2017, Campomizzi et al. 2019, Pintaric et al. 2019). In contrast, Bleho et al. (2014) found that rates of trampling of grassland bird nests by cattle were low in Canada, although the majority of their data were from grasslands in Alberta, Saskatchewan, and Manitoba, with a small sample of duck nests in the Great Lakes-St. Lawrence Lowlands in Québec where nest destruction by cattle was highest. Bleho et al. (2014) attributed high nest destruction to the high primary productivity of the Great Lakes-St. Lawrence Lowlands, which enabled higher cattle stocking rates. Because our study sites were located in the Great Lakes-St. Lawrence Lowlands, high primary productivity across the region provides an explanation as to why we observed high stocking rates, which, in turn, had a strong impact on daily survival rates of Bobolink nests because of increased trampling risk or reduced vegetative cover, or both (Jensen et al. 1990, Sutter and Ritchison 2005, Perlut and Strong 2011, MacDonald and Nol 2017).

Our model results predicting daily survival rate across cattle stocking rates suggest there is a potential threshold at $\sim 40$ cattledays/ha, above which the daily survival rate of Bobolink nests rapidly decreases. Our observed nest failure results support this potential threshold because $64 \%$ of trampled nests ( 21 of 33 ) occurred in rotationally grazed pastures where stocking rates were greater than 40 cattle-days/ha. Perlut et al. (2006) found that $65 \%$ of Bobolink nest failures ( 22 of 34 ) in rotationally grazed pastures were caused by cattle disturbance, with grazing pressures described as 1-1.5 cattle/0.4 ha (2.5-3.75 cattle/ha) rotated every 7-14 days. In contrast, at much lower stocking rates than we observed in our study and in Perlut et al. (2006), Kerns et al. (2010) found that only $1 \%$ of Bobolink nest failures ( 1 of 91 ) were caused by trampling in grazed pastures with stocking rates of $0.20-0.28$ animal unit months/ha (animal unit month = the average amount of forage required by a lactating 1000-pound cow and her calf for one month, i.e., 30.4 days). Because stocking rates are often higher in rotationally grazed pastures than in continuously grazed pastures (Jensen et al. 1990), nest survival can vary across grazing systems. For example, Temple et al. (1999) found that rotationally grazed pastures (typically $40-60$ cattle/ha grazed in $\sim 5$ ha pastures for 1-2 days) had the lowest nest survival, continuously grazed pastures (2.5-4 cattle/ha grazed 16 sites totaling 91 ha for $\sim 48$ days) had intermediate nest survival and ungrazed fields (neither mowed nor grazed during the study period) had the highest nest survival. However, our results suggest that stocking rate while most nests are active is a better predictor of the daily survival rate of Bobolink nests in pastures than the type of grazing system used (i.e., rotational or continuous grazing).

Date of the breeding season was the other important predictor variable negatively associated with daily survival rate of Bobolink nests. Other studies have reported a similar negative relationship in which daily survival rate of grassland bird nests decreases throughout the breeding season (Jehle et al. 2004, Winter et al. 2004, Grant et al. 2005). Because nest predation was the most common cause of nest failure in our study, the decline in daily survival rate across the breeding season may correspond to an increase in predator abundance and an increase in predator movements as the season progresses (Grant et al. 2005). Daily 
survival rate of nests may also decrease over the breeding season because of the decline of prey availability, as reported for the Lark Bunting (Calamospiza melanocorys), which experienced similar decreases in daily survival rate over the breeding season corresponding to a decline in the availability of grasshoppers (Orthoptera spp.; the main prey fed to nestlings), a pattern typical of summers in northern Colorado, U.S. (Jehle et al. 2004). Regardless of the potential causes, our results suggest that nests initiated partway through the breeding season (e.g., renesting attempts or nests initiated by adults that arrive late) had a decreased probability of survival compared to nests initiated at the beginning of the season.

Region, field use, field area, and distance to forest edge were not good predictors of the daily survival rate of Bobolink nests in our study. Despite differences in landscape composition that could potentially influence differences in nest predator assemblages, we did not find support for our prediction that greater grassland cover and less forest cover would promote higher nest survival. Our results echo those of other grassland passerine studies which suggest that landscape composition has no significant effect on daily survival rate of nests (McMaster et al. 2005, Winter et al. 2005, 2006, Koper and Schmiegelow 2006). Although Bobolink population trends (Ethier et al. 2017) and patterns of area sensitivity (Vickery and Herkert 2001) appear to vary by region, our results suggest that daily survival rate of Bobolink nests did not vary significantly across the regions within the management regimes we studied, even with differences in land use. Our results suggest that the categorical variable, field use (i.e., rotationally grazed pasture, continuously grazed pasture, ungrazed pasture, hayfield, fallow field, and restored grassland) is not an important predictor of daily survival rate of Bobolink nests. This is likely because the continuous variable stocking rate provides a better overall representation of grazing pressure or lack thereof (i.e., hayfields, ungrazed pastures, restored fields, fallow fields, and pastures grazed before 21 May or after 23 June had a stocking rate of 0 cattle-days/ha). Additionally, in some grazed pastures with low stocking rates, Bobolinks still reproduced successfully (MacDonald and Nol 2017, Campomizzi et al. 2019, Pintaric et al. 2019). Although we categorized fields based on their use, there are probably within-field variables that help to explain nest survival when cattle are not present, e.g., vegetation density (Warren and Anderson 2005) and vegetation height (Pintaric et al. 2019) around each nest. In contrast to Johnson and Temple (1990) and Herkert et al. (2003), we found no significant association between field area and daily survival rate of nests, possibly because the area of the fields we monitored were mostly smaller than those in these other studies. Similar to Renfrew et al. (2005) and Perkins et al. (2013), but in contrast with Bollinger and Gavin (2004), we found no significant association between the distance to forest edge and daily survival rate of nests, although as stated by Renfrew et al. (2005) it is possible that effects of predators associated with open grasslands mask the effects of predators associated with edges.

Our results have implications for the conservation of nesting Bobolinks regarding field use, stocking rate, date, and field size. All field types we studied have potential for conservation actions because daily survival rate of nests did not vary across late-cut hayfields, fallow fields, restored grasslands, or pastures, although stocking rate was important in pastures. Pastures grazed lightly (i.e., stocking rates $\leq 40$ cattle-days/ha) while most Bobolink nests are active can also potentially provide successful nesting habitat by limiting nest failure caused by cattle. Minimizing management practices that delay early-season nesting (e.g., heavy late-season grazing or hay harvest the previous autumn) or inadvertently destroying early season nests (e.g., heavy grazing) should be avoided in fields where Bobolink conservation is a priority because we found daily survival rate of nests decreased across the season. Lastly, our results suggest that small fields can provide productive nesting habitat for Bobolinks, because daily survival rate of nests did not vary with field area in our study (1.4-161.8 ha). However, field size might have an impact on breeding densities (Herkert 1994, Vickery et al. 1994, as cited in Ethier and Nudds 2017), and, as such, fields with higher breeding densities should be targeted to have the greatest benefit on recruitment to the population. Landowners and managers may require incentives (e.g., financial, regulatory, technical assistance) to enable the implementation of conservation actions that promote increased Bobolink nest survival (e.g., light grazing, delayed hay harvest, field left ungrazed as nesting refuge), but interfere with agricultural activity (MacDonald and Nol 2017, Campomizzi et al. 2019, Pintaric et al. 2019).

\section{Responses to this article can be read online at: http://www.ace-eco.org/issues/responses.php/1666}

\section{Acknowledgments:}

We thank the private landowners involved in this project, Couchiching Conservancy, Grand River Conservation Authority, Ontario Ministry of Natural Resources and Forestry, Lafarge Aggregates, and Nature Conservancy of Canada for generously allowing us to study Bobolinks on their land. We are grateful for field assistance from M. Bateman, N. Conroy, C. Curran, A. Disher, J. Fortier, M. Hawkins, J. Horvat, B. LeClaire, K. Mancuso, K. Manson, E. Moore, G. Moore, G. Morris, J. Put, D. Stonley, C. Street, and J. Turgeon. We thank C. Lituma for project guidance. Funding was provided by (1) the Government of Ontario; (2) the Ontario Soil and Crop Improvement Association, through the Species at Risk Farm Incentive Program (SARFIP) and the Species at Risk Partnerships on Agricultural Lands (SARPAL) program, an Environment and Climate Change Canada initiative; (3) Echo Foundation; (4) Colleges and Institutes Canada, CareerLauncher Internship program; (5) Bird Studies Canada; (6) The Schad Foundation; (7) The McLean Foundation; (8) the Mitacs Accelerate program; (9) an Ontario Graduate Scholarship; (10) Trent University; and (11) individual donors. This research was conducted under permission from the Canadian Wildlife Service and in compliance with the Endangered Species Act, 2007 and Trent University Animal Care Protocols (\#'s 22840, 23981, 25288). The views expressed herein are those of the authors, not funders or other entities.

\section{LITERATURE CITED}

Akaike, H. 1973. Information theory and an extension of the maximum likelihood principle. Pages 267-281 in B. N. Petrov and F. Csaki, editors. Second International Symposium on Information Theory. Akademiai Kiado, Budapest, Hungary. 
Agriculture and Agri-Food Canada (AAFC). 2018. Annual crop inventory 2012, 2013, 2015, 2016 and 2017. Agriculture and AgriFood Canada, Ottawa, Canada. [online] URL: http://www.agr. gc.ca/atlas/data_donnees/agr/annualCropInventory/tif/

Agriculture and Agri-Food Canada (AAFC). 2019a. Annual crop inventory 2018. Agriculture and Agri-Food Canada, Ottawa, Canada. [online] URL:http://www.agr.gc.ca/atlas/data_donnees/ agr/annualCropInventory/tif/2018/

Agriculture and Agri-Food Canada (AAFC). 2019b. Annual crop inventory - Data product specifications. Agriculture and AgriFood Canada, Ottawa, Canada. [online] URL: http://www.agr. gc.ca/atlas/supportdocument_documentdesupport/annualCropInventory/ en/ISO\%2019131_AAFC_Annual_Crop_Inventory_Data_Product_Specifications.pdf

Arnold, T. W. 2010. Uninformative parameters and model selection using Akaike's information criterion. Journal of Wildlife Management 74:1175-1178. https://doi.org/10.1111/j.1937-2817.2010. tb01236.x

Bergin, T. M., L. B. Best, K. E. Freemark, and K. J. Koehler. 2000. Effects of landscape structure on nest predation in roadsides of a midwestern agroecosystem: a multiscale analysis. Landscape Ecology 15:131-143. https://doi.org/10.1023/A:1008112825655

Bleho, B. I., N. Koper, and C. S. Machtans. 2014. Direct effects of cattle on grassland birds in Canada. Conservation Biology 28:724-734. https://doi.org/10.1111/cobi.12259

Bollinger, E. K., and T. A. Gavin. 2004. Responses of nesting Bobolinks (Dolichonyx oryzivorus) to habitat edges. Auk 121:767-776.

Burnham, K. P., and D. R. Anderson. 2002. Model selection and multi-model inference: a practical information-theoretic approach. Second edition. Springer, New York, New York, USA.

Burnham, K. P., D. R. Anderson, and K. P. Huyvaert. 2011. AIC model selection and multimodel inference in behavioral ecology: some background, observations, and comparisons. Behavioral Ecology and Sociobiology 65:23-35. https://doi.org/10.1007/ s00265-010-1029-6

Cadman, M. D., D. A. Sutherland, G. G. Beck, D. Lepage, and A. R. Couturier. 2007. Atlas of the breeding birds of Ontario, 2001-2005. Bird Studies Canada, Environment Canada, Ontario Field Ornithologists, Ontario Ministry of Natural Resources, and Ontario Nature. Toronto, Ontario, Canada. [online] URL: http:// birdsontario.org/atlas/maps.jsp?lang=en

Campomizzi, A. J., Z. M. Lebrun-Southcott, L. D. Van Vliet, and G. A. Morris. 2019. Rotational grazing of beef cattle to support Bobolink breeding success. Avian Conservation and Ecology 14 (2):13. https://doi.org/10.5751/ACE-01420-140213

Davis, S. K. 2003. Nesting ecology of mixed-grass prairie songbirds in southern Saskatchewan. Wilson Bulletin 115:119-130. https://doi.org/10.1676/02-138

Dinsmore, S. J., and J. J. Dinsmore. 2007. Modeling avian nest survival in program MARK. Studies in Avian Biology 34:73-83. [online] URL: https://lib.dr.iastate.edu/cgi/viewcontent.cgi?referer= https://www.google.com/\&httpsredir=1\&article=1087\&context= nrem_pubs
Dinsmore, S. J., G. C. White, and F. L. Knopf. 2002. Advanced techniques for modeling avian nest survival. Ecology 83:3476-3488. https://doi.org/10.1890/0012-9658(2002)083[3476: ATFMAN]2.0.CO;2

Ellison, K. S., C. A. Ribic, D. W. Sample, M. J. Fawcett, and J. D. Dadisman. 2013. Impacts of tree rows on grassland birds and potential nest predators: a removal experiment. PLOS ONE 8: e59151. https://doi.org/10.1371/journal.pone.0059151

Ethier, D. M., N. Koper, and T. D. Nudds. 2017. Spatiotemporal variation in mechanisms driving regional-scale population dynamics of a threatened grassland bird. Ecology and Evolution 7:4152-4162. https://doi.org/10.1002/ece3.3004

Ethier, D. M., and T. D. Nudds. 2017. Complexity of factors affecting Bobolink population dynamics communicated with directed acyclic graphs. Wildlife Society Bulletin 41:4-16. https:// doi.org/10.1002/wsb.739

Evans, J. D. 1996. Straight forward statistics for the behavioral sciences. Brooks/Cole, Pacific Grove, California, USA.

George, T. L., A. C. Fowler, R. L. Knight, and L. C. McEwen. 1992. Impacts of a severe drought on grassland birds in western North Dakota. Ecological Applications 2:275-284. https://doi. org/10.2307/1941861

Government of Canada. 2017. Species profile: Bobolink. Environment Canada, Ottawa, Canada. [online] URL: https:// wildlife-species.canada.ca/species-risk-registry/species/speciesDetails_e. $\mathrm{cfm}$ ?sid= 1087

Government of Ontario. 2019. Species at risk in Ontario. Ministry of the Environment, Conservation and Parks, Peterborough, Ontario, Canada. [online] URL: https://www.ontario.ca/page/ species-risk-ontario

Grant, T. A., T. L. Shaffer, E. M. Madden, and P. J. Pietz. 2005. Time-specific variation in passerine nest survival: new insights into old questions. Auk 122:661-672. https://doi.org/10.1093/ auk/122.2.661

Greenwood, R. J., A. B. Sargeant, D. H. Johnson, L. M. Cowardin, and T. L. Shaffer. 1995. Factors associated with duck nest success in the prairie pothole region of Canada. Wildlife Monographs 128:3-57. [online] URL: https://digitalcommons.unl. edu/cgi/viewcontent.cgi?referer=https://www.google.com/ \&httpsredir $=1 \&$ article $=1243 \&$ context $=$ usgsnpwrc

Guilherme, J. L., R. J. Burnside, N. J. Collar, and P. M. Dolman. 2018. Consistent nest-site selection across habitats increases fitness in Asian Houbara. Auk 135:192-205. https://doi. org/10.1642/AUK-17-156.1

Guthery, F. S., and R. L. Bingham. 1996. A theoretical basis for study and management of trampling by cattle. Journal of Range Management 49:264-269. https://doi.org/10.2307/4002889

Herkert, J. R. 1997. Bobolink Dolichonyx oryzivorus population decline in agricultural landscapes in the Midwestern USA. Biological Conservation 80:107-112. https://doi.org/10.1016/ S0006-3207(96)00066-3

Herkert, J. R., D. W. Sample, and R. E. Warner. 1996. Management of midwestern grassland landscapes for the 
conservation of migratory birds. Pages $89-116$ in F. R. Thompson, III, editor. Management of midwestern landscapes for the conservation of neotropical migratory birds. General Technical Report. USDA Forest Service, Detroit, Michigan, USA. [online] URL: https://www.nrs.fs.fed.us/pubs/gtr/other/gtr-nc187/Page \% 2089\%20JR\%20Herkert,\%20NC-GTR-187.pdf

Herkert, J. R., D. L. Reinking, D. A. Wiedenfeld, M. Winter, J. L. Zimmerman, W. E. Jensen, E. J. Finck, R. R. Koford, D. H. Wolfe, S. K. Sherrod, M. A. Jenkins, J. Faaborg, and S. K. Robinson. 2003. Effects of prairie fragmentation on the nest success of breeding birds in the midcontinental United States. Conservation Biology 17:587-594. https://doi.org/10.1046/ j.1523-1739.2003.01418.x

Horn, D. J., M. L. Phillips, R. R. Koford, W. R. Clark, M. A. Sovada, and R. J. Greenwood. 2005. Landscape composition, patch size, and distance to edges: interactions affecting duck reproductive success. Ecological Applications 15:1367-1376. https://doi.org/10.1890/03-5254

Hurvich, C. M., and C.-L. Tsai. 1989. Regression and time series model selection in small samples. Biometrika 76:297-307. https:// doi.org/10.1093/biomet/76.2.297

Jehle, G., A. A. Yackel Adams, J. A. Savidge, and S. K. Skagen. 2004. Nest survival estimation: a review of alternatives to the Mayfield estimator. Condor 106:472-484. https://doi.org/10.1093/ condor/106.3.472

Jensen, H. P., D. Rollins, and R. L. Gillen. 1990. Effects of cattle stock density on trampling loss of simulated ground nests. Wildlife Society Bulletin 18:71-74.

Johnson, R. G., and S. A. Temple. 1990. Nest predation and brood parasitism of tallgrass prairie birds. Journal of Wildlife Management 54:106-111. https://doi.org/10.2307/3808909

Jones, J., P. J. Doran, L. R. Nagy, and R. T. Holmes. 2005. Relationship between Mayfield nest-survival estimates and seasonal fecundity: a cautionary note. Auk 122:306-312. https:// doi.org/10.1093/auk/122.1.306

Kerns, C. K., M. R. Ryan, R. K. Murphy, F. R. Thompson, III, and C. S. Rubin. 2010. Factors affecting songbird nest survival in northern mixed-grass prairie. Journal of Wildlife Management 74:257-264. https://doi.org/10.2193/2008-249

Koper, N., and F. K. K. Schmiegelow. 2006. A multi-scaled analysis of avian response to habitat amount and fragmentation in the Canadian dry mixed-grass prairie. Landscape Ecology 21:1045-1059. https://doi.org/10.1007/s10980-006-0004-0

Laake, J. L. 2013. RMark: an R interface for analysis of capturerecapture data with $M A R K$. Alaska Fisheries Science Center, National Oceanic and Atmospheric Administration, National Marine Fisheries Service, Seattle, Washington, USA.

Laake, J. L., and E. Rexstad. 2008. RMark - an alternative approach to building linear models in MARK. Appendix C in E. G. Cooch, and G. C. White, editors. Program MARK - a gentle introduction. Colorado State University, Fort Collins, USA. [online] URL: http://www.phidot.org/software/mark/docs/book/

Lanyon, W. E. 1957. The comparative biology of the meadowlarks (Sturnella) in Wisconsin. Publications of the Nuttall Ornithological Club no. 1, Cambridge, Massachusetts, USA.
MacDonald, N. M., and E. Nol. 2017. Impacts of rotational grazing and hay management on the reproductive success of Bobolink (Dolichonyx oryzivorus) in eastern Ontario, Canada. Canadian Wildlife Biology and Management 6:53-65. [online] URL: http://cwbm.name/impacts-of-rotational-grazing-and-haymanagement-on-the-reproductive-success-of-bobolink-dolichonyxoryzivorus-in-eastern-ontario-canada/

Martin, S. G. 1974. Adaptations for polygynous breeding in the Bobolink, Dolichonyx oryzivorus. American Zoologist 14:109-119. https://doi.org/10.1093/icb/14.1.109

Martin, T. E. 1993. Nest predation among vegetation layers and habitat types: revising the dogmas. American Naturalist 141:897-913. https://doi.org/10.1086/285515

Martin, T. E., and G. R. Geupel. 1993. Nest-monitoring plots: methods for locating nests and monitoring success. Journal of Field Ornithology 64:507-519. [online] URL: https://sora.unm. edu/sites/default/files/journals/jfo/v064n04/p0507-p0519.pdf

Mayfield, H. 1961. Nesting success calculated from exposure. Wilson Bulletin 73:255-261.

McMaster, D. G., J. H. Devries, and S. K. Davis. 2005. Grassland bird nesting in haylands of southern Saskatchewan: landscape influences and conservation priorities. Journal of Wildlife Management 69:211-221. https://doi.org/10.2193/0022-541X (2005)069<0211:GBNIHO>2.0.CO;2

Ontario Ministry of Agriculture, Food and Rural Affairs (OMAFRA). 2012. Rotational grazing in extensive pastures. Ontario Ministry of Agriculture, Food and Rural Affairs, Guelph, Ontario, Canada. [online] URL: http://www. ontariosoilcrop.org/wp-content/uploads/2015/08/

rotational_grazing_in_extensive_pastures.sm_.pdf

Ontario Ministry of Natural Resources and Forestry (OMNRF). 2015. Bobolink and Eastern Meadowlark government response statement. Ontario Ministry of Natural Resources and Forestry, Peterborough, Ontario, Canada. [online] URL: https://www. ontario.ca/page/bobolink-and-eastern-meadowlark-governmentresponse-statement

Paine, L., D. J. Undersander, D. W. Sample, G. A. Bartelt, and T. A. Schatteman. 1996. Cattle trampling of simulated ground nests in rotationally grazed pastures. Journal of Range Management 49:294-300. https://doi.org/10.2307/4002586

Patterson, M. P., and L. B. Best. 1996. Bird abundance and nesting success in Iowa CRP fields: the importance of vegetation structure and composition. American Midland Naturalist 135:153-167. https://doi.org/10.2307/2426881

Perkins, D. G., N. G. Perlut, and A. M. Strong. 2013. Minor fitness benefits for edge avoidance in nesting grassland birds in the northeastern United States. Auk 130:512-519. https://doi. org/10.1525/auk.2013.12163

Perlut, N. G., and A. M. Strong. 2011. Grassland birds and rotational-grazing in the northeast: breeding ecology, survival and management opportunities. Journal of Wildlife Management 75:715-720. https://doi.org/10.1002/jwmg.81

Perlut, N. G., A. M. Strong, T. M. Donovan, and N. J. Buckley. 2006. Grassland songbirds in a dynamic management landscape: behavioral responses and management strategies. Ecological 
Applications 16:2235-2247. https://doi.org/10.1890/1051-0761 (2006)016[2235:GSIADM]2.0.CO;2

Phillips, M. L., W. R. Clark, M. A. Sovada, D. J. Horn, R. R. Koford, and R. J. Greenwood. 2003. Predator selection of prairie landscape features and its relation to duck nest success. Journal of Wildlife Management 67:104-114. https://doi.org/10.2307/3803066

Pietz, P. J., and D. A. Granfors. 2000. Identifying predators and fates of grassland passerine nests using miniature video cameras. Journal of Wildlife Management 64:71-87. https://doi. org/10.2307/3802976

Pintaric, A., R. Reid, and E. Nol. 2019. Variation in surrogate breeding habitat quality between continuously-grazed rangelands and late-cut hayfields for a threatened grassland bird. Rangeland Ecology and Management 72:474-483. https://doi.org/10.1016/j. rama.2019.01.001

R Core Team. 2016. R: a language and environment for statistical computing. R Foundation for Statistical Computing, Vienna, Austria. [online] URL https://www.r-project.org/

Renfrew, R. B., C. A. Ribic, and J. L. Nack. 2005. Edge avoidance by nesting grassland birds: a futile strategy in a fragmented landscape. Auk 122:618-636. https://doi.org/10.1093/auk/122.2.618

Renfrew, R., A. M. Strong, N. G. Perlut, S. G. Martin, and T. A. Gavin. 2015. Bobolink (Dolichonyx oryzivorus), version 1.0. In P. G. Rodewald, editor. The birds of the world. Cornell Lab of Ornithology, Ithaca, New York, USA. [online] URL: https:// birdsoftheworld.org/bow/species/boboli/cur/introduction https:// doi.org/10.2173/bow.boboli.01

Reynolds, R. E., T. L. Shaffer, R. W. Renner, W. E. Newton, and B. D. J. Batt. 2001. Impact of the conservation reserve program on duck recruitment in the U.S. prairie pothole region. Journal of Wildlife Management 65:765-780. https://doi.org/10.2307/3803027

Ricklefs, R. E. 1969. An analysis of nesting mortality in birds. Smithsonian Contributions to Zoology 9:1-48. https://doi. org/10.5479/si.00810282.9

Rosenberg, K. V., A. M. Dokter, P. J. Blancher, J. R. Sauer, A. C. Smith, P. A. Smith, J. C. Stanton, A. Panjabi, L. Helft, M. Parr, and P. P. Marra. 2019. Decline of the North American avifauna. Science 366:120-124. https://doi.org/10.1126/science.aaw1313

Rotella, J. J. 2007. Modeling nest-survival data: recent improvements and future directions. Studies in Avian Biology 34:145-148. [online] URL: https://sora.unm.edu/sites/default/ files/SAB_034_2007\%20P145-148_Modeling $\% 20$ Nest-Survival $\%$ 20Data $\% 20-\% 20$ Recent $\% 20$ Improvements $\% 20$ and $\% 20$ Future $\%$ 20Directions_Jay\%20Rotella.pdf

Rotella, J. J. 2009. Nest survival models. Chapter 17 in E. G. Cooch and G. C. White, editors. Program MARK - a gentle introduction. Colorado State University, Fort Collins, USA. [online] URL: http://www.phidot.org/software/mark/docs/book/pdf/chap17.pdf

Rotella, J. J., S. J. Dinsmore, and T. L. Shaffer. 2004. Modeling nest-survival data: a comparison of recently developed methods that can be implemented in MARK and SAS. Animal Biodiversity and Conservation 27:187-205. [online] URL: https://www. researchgate.net/publication/26410955_Modeling_nestsurvival_data_A_comparison_of_recently_developed_methods_-
that_can_be_implemented_in_MARK_and_SAS/

fulltext/0e6053def0c46d4f0ab02e91/Modeling-nest-survival-dataA-comparison-of-recently-developed-methods-that-can-be-implementedin-MARK-and-SAS.pdf

Sauer, J. R., W. A. Link, J. E. Fallon, K. L. Pardieck, and D. J. Ziolkowski, Jr. 2013. The North American Breeding Bird Survey 1966-2011: summary analysis and species accounts. North American Fauna 79:1-32. https://doi.org/10.3996/nafa.79.0001

Sauer, J. R., K. L. Pardieck, D. J. Ziolkowski, Jr., A. C. Smith, M. A. R. Hudson, V. Rodriguez, H. Berlanga, D. K. Niven, and W. A. Link. 2017. The first 50 years of the North American Breeding Bird Survey. Condor 119:576-593. https://doi. org/10.1650/CONDOR-17-83.1

Smith, A. C., M.-A. R. Hudson, V. Aponte, and C. M. Francis. 2019. North American Breeding Bird Survey - Canadian trends website, data-version 2017. Environment and Climate Change Canada, Gatineau, Quebec, Canada. [online] URL: https:// wildlife-species.canada.ca/breeding-bird-survey-results/P004/A001/? lang $=\mathrm{e} \& \mathrm{~m}=\mathrm{s} \& \mathrm{r}=\mathrm{BOBO} \& \mathrm{p}=\mathrm{L}$

Sutter, B., and G. Ritchison. 2005. Effects of grazing on vegetation structure, prey availability, and reproductive success of Grasshopper Sparrows. Journal of Field Ornithology 76:345-351. https://doi.org/10.1648/0273-8570-76.4.345

Temple, S. A., B. M. Fevold, L. K. Paine, D. J. Undersander, and D. W. Sample. 1999. Nesting birds and grazing cattle: accommodating both on midwestern pastures. Studies in Avian Biology 19:196-202. [online] URL: https://sora.unm.edu/sites/ default/files/SAB_019_1999\%20P196-202_Nesting $\% 20$ Birds $\% 20$ and $\%$ 20Grazing $\% 20$ Cattle $\% 20$ Accommodating $\% 20$ Both $\% 20$ on $\%$

20 Midwesterm $\% 20$ Pastures_Temple $\% 2 \mathrm{C} \% 20$ Fevold $\% 2 \mathrm{C} \% 20$ Paine $\%$ 2C $\% 20$ Undersander $\% 2 \mathrm{C} \% 20$ Sample.pdf

Tewksbury, J. J., L. Garner, S. Garner, J. D. Lloyd, V. Saab, and T. E. Martin. 2006. Tests of landscape influences: nest predation and brood parasitism in fragmented ecosystems. Ecology 87:759-768. https://doi.org/10.1890/04-1790

Vickery, P. D., and J. R. Herkert. 2001. Recent advances in grassland bird research: where do we go from here? Auk 118:11-15. https://doi.org/10.1093/auk/118.1.11

Walker, J., J. J. Rotella, S. E. Stephens, M. S. Lindberd, J. K. Ringelman, C. Hunter, and A. J. Smith. 2013. Time-lagged variation in pond density and primary productivity affects duck nest survival in the prairie pothole region. Ecological Applications 23:1061-1074. https://doi.org/10.1890/12-1755.1

Warren, K. A., and J. T. Anderson. 2005. Grassland songbird nest-site selection and response to mowing in West Virginia. Wildlife Society Bulletin 33:285-292. https://doi.org/10.2193/0091-7648 (2005)33[285:GSNSAR]2.0.CO;2

Winter, M. 1999. Nesting biology of Dickcissels and Henslow's Sparrows in southwestern Missouri prairie fragments. Wilson Bulletin 11:515-527. [online] URL: https://sora.unm.edu/sites/ default/files/journals/wilson/v111n04/p0515-p0526.pdf

Winter, M., S. E. Hawks, J. A. Shaffer, and D. H. Johnson. 2003. Guidelines for finding nests of passerine birds in tallgrass prairie. Prairie Naturalist 35:197-211. [online] URL: https://digitalcommons. unl.edu/cgi/viewcontent.cgi? article $=1159 \&$ context $=$ usgsnpwrc 
Winter, M., D. H. Johnson, J. A. Shaffer, T. M. Donovan, and W. D. Svedarsky. 2006. Patch size and landscape effects on density and nesting success of grassland birds. Journal of Wildlife Management 70:158-172. https://doi.org/10.2193/0022-541X (2006)70[158:PSALEO]2.0.CO;2

Winter, M., D. H. Johnson, J. A. Shaffer, and W. D. Svedarsky. 2004. Nesting biology of three grassland passerines in the northern tallgrass prairie. Wilson Bulletin 116:211-223. https:// doi.org/10.1676/03-082

Winter, M., J. A. Shaffer, D. H. Johnson, T. M. Donovan, W. D. Svedarsky, P. W. Jones, and B. R. Euliss. 2005. Habitat and nesting of Le Conte's sparrow in the northern tallgrass prairie. Journal of Field Ornithology 76:61-71. https://doi.org/10.1648/0273-8570-76.1.61

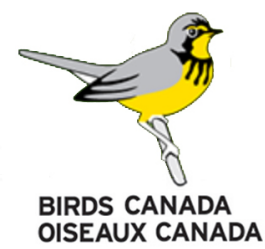


Appendix 1. Additional information including summary statistics of landscape variables and their correlations, and the full model selection results.

Table A1.1. Summary statistics (\%) for the landscape variables within a 2, 5, and $10 \mathrm{~km}$ buffer around each nest, collated for 463 Bobolink nests.

\begin{tabular}{|c|c|c|c|c|c|}
\hline Buffer distance & Land cover type (\%) & Mean & Median & Min. & Max. \\
\hline \multirow[t]{5}{*}{$2 \mathrm{~km}$} & Grassland $^{\dagger}$ & 32 & 27 & 9 & 68 \\
\hline & Cropland $^{\dagger}$ & 21 & 17 & 0 & 61 \\
\hline & Forest $^{\dagger}$ & 21 & 19 & 4 & 54 \\
\hline & Wetland & 14 & 7 & 0 & 63 \\
\hline & Shrubland & 6 & 5 & 1 & 29 \\
\hline \multirow[t]{5}{*}{$5 \mathrm{~km}$} & Grassland & 26 & 24 & 9 & 51 \\
\hline & Cropland & 25 & 20 & 0 & 54 \\
\hline & Forest $^{\dagger}$ & 22 & 21 & 10 & 46 \\
\hline & Wetland & 11 & 5 & 0 & 55 \\
\hline & Shrubland & 6 & 4 & 1 & 20 \\
\hline \multirow[t]{5}{*}{$10 \mathrm{~km}$} & Grassland $^{\dagger}$ & 23 & 22 & 10 & 57 \\
\hline & Cropland & 25 & 14 & 1 & 54 \\
\hline & Forest & 28 & 28 & 11 & 57 \\
\hline & Wetland & 9 & 6 & 0 & 37 \\
\hline & Shrubland & 6 & 5 & 2 & 16 \\
\hline
\end{tabular}

${ }^{\dagger}$ Indicates landscape variables included in the analysis. 
Table A1.2. Correlation matrix between percent land cover types at 10, 5, and $2 \mathrm{~km}$ buffers around Bobolink nests ( $n=463)$. Variables were considered highly correlated when $|r| \geq 0.60$.

\begin{tabular}{|c|c|c|c|c|c|c|c|c|c|c|c|c|c|c|c|}
\hline & $\begin{array}{r}\text { Crop } \\
10 \\
\end{array}$ & $\begin{array}{r}\text { Forest } \\
10 \\
\end{array}$ & $\begin{array}{r}\text { Pasture } \\
10 \\
\end{array}$ & $\begin{array}{r}\text { Shrub } \\
10 \\
\end{array}$ & $\begin{array}{r}\text { Wetland } \\
10\end{array}$ & $\begin{array}{r}\text { Crop } \\
5\end{array}$ & $\begin{array}{r}\text { Forest } \\
5\end{array}$ & $\begin{array}{r}\text { Pasture } \\
5 \\
\end{array}$ & $\begin{array}{r}\text { Shrub } \\
5\end{array}$ & $\begin{array}{r}\text { Wetland } \\
5\end{array}$ & $\begin{array}{r}\text { Crop } \\
2 \\
\end{array}$ & $\begin{array}{r}\text { Forest } \\
2 \\
\end{array}$ & $\begin{array}{r}\text { Pasture } \\
2 \\
\end{array}$ & $\begin{array}{r}\text { Shrub } \\
2 \\
\end{array}$ & $\begin{array}{r}\text { Wetland } \\
2\end{array}$ \\
\hline Crop10 & 1.00 & & & & & & & & & & & & & & \\
\hline Forest10 & -0.75 & 1.00 & & & & & & & & & & & & & \\
\hline Pasture10 & 0.23 & -0.01 & 1.00 & & & & & & & & & & & & \\
\hline Shrub10 & -0.74 & 0.27 & -0.24 & 1.00 & & & & & & & & & & & \\
\hline Wetland10 & -0.43 & -0.18 & -0.54 & 0.68 & 1.00 & & & & & & & & & & \\
\hline Crop5 & 0.93 & -0.57 & 0.32 & -0.76 & -0.59 & 1.00 & & & & & & & & & \\
\hline Forest5 & -0.60 & 0.82 & 0.05 & 0.12 & -0.28 & -0.52 & 1.00 & & & & & & & & \\
\hline Pasture5 & -0.30 & 0.64 & 0.53 & -0.08 & -0.59 & -0.10 & 0.47 & 1.00 & & & & & & & \\
\hline Shrub5 & -0.71 & 0.21 & -0.30 & 0.95 & 0.70 & -0.79 & 0.15 & -0.16 & 1.00 & & & & & & \\
\hline Wetland5 & -0.39 & -0.21 & -0.54 & 0.66 & 0.99 & -0.57 & -0.34 & -0.61 & 0.70 & 1.00 & & & & & \\
\hline Crop2 & 0.66 & -0.34 & 0.32 & -0.58 & -0.54 & 0.82 & -0.37 & 0.02 & -0.65 & -0.55 & 1.00 & & & & \\
\hline Forest2 & -0.13 & 0.15 & 0.06 & -0.07 & -0.13 & -0.21 & 0.50 & 0.05 & 0.04 & -0.09 & -0.51 & 1.00 & & & \\
\hline Pasture2 & -0.34 & 0.73 & 0.25 & -0.05 & -0.48 & -0.17 & 0.49 & 0.86 & -0.15 & -0.51 & 0.00 & -0.19 & 1.00 & & \\
\hline Shrub2 & -0.54 & 0.06 & -0.17 & 0.81 & 0.57 & -0.65 & 0.16 & -0.19 & 0.88 & 0.55 & -0.64 & 0.26 & -0.30 & 1.00 & \\
\hline Wetland2 & -0.19 & -0.35 & -0.50 & 0.52 & 0.87 & -0.41 & -0.37 & -0.69 & 0.59 & 0.09 & -0.58 & 0.06 & -0.63 & 0.53 & 1.00 \\
\hline
\end{tabular}


Table A1.3. Full model selection results for daily survival rate of Bobolink nests explained by local, landscape, and temporal covariates, ranked by Akaike's Information Criterion (AICc) for 463 nests. The table includes all 53 models (including null $=$ model 39).

\begin{tabular}{|c|c|c|c|c|c|}
\hline No. & Nest survival models & $\mathrm{K}^{\dagger}$ & $\triangle \mathrm{AICc} *$ & $\begin{array}{l}\text { AICc } \\
\text { weight }\end{array}$ & $\operatorname{Dev}^{\S}$ \\
\hline 1 & Date + Stocking rate $\left.\right|^{*}$ & 3 & 0.00 & 0.16 & 1120.54 \\
\hline 2 & Date + Stocking rate + Forest $2^{\mathbb{I}}+$ Forest $5^{\#}$ & 5 & 0.02 & 0.15 & 1116.55 \\
\hline 3 & Date + Stocking rate + Forest 2 & 4 & 0.33 & 0.13 & 1118.87 \\
\hline 4 & Date + Stocking rate + Grassland $2^{\dagger \dagger}$ & 4 & 0.85 & 0.10 & 1119.39 \\
\hline 5 & Date + Stocking rate + Grassland $10 \$$ & 4 & 1.17 & 0.09 & 1119.71 \\
\hline 6 & Date + Stocking rate + Forest 5 & 4 & 1.28 & 0.08 & 1119.81 \\
\hline 7 & Date + Stocking rate + Crop $2^{\S \S}$ & 4 & 1.97 & 0.06 & 1120.51 \\
\hline 8 & Date + Stocking rate + Crop $2+$ Forest $2+$ Grassland 10 & 6 & 2.16 & 0.05 & 1116.68 \\
\hline 9 & Date + Stocking rate + Grassland $2+$ Grassland 10 & 5 & 2.35 & 0.05 & 1118.88 \\
\hline 10 & $\begin{array}{l}\text { Date }+ \text { Stocking rate }+ \text { Crop } 2+\text { Forest } 2+\text { Forest } 5+ \\
\text { Grassland } 2+\text { Grassland } 10\end{array}$ & 8 & 3.50 & 0.03 & 1114.01 \\
\hline 11 & Date + Stocking rate + Crop $2+$ Forest $2+$ Grassland 2 & 6 & 3.54 & 0.03 & 1118.06 \\
\hline 12 & Date + Stocking rate + Field use || & 8 & 3.76 & 0.02 & 1114.28 \\
\hline 13 & Date + Stocking rate + Region ${ }^{\text {IIII }}$ & 6 & 4.13 & 0.02 & 1118.66 \\
\hline 14 & Date + Stocking rate + Crop $2+$ Forest $5+$ Grassland 10 & 6 & 4.51 & 0.02 & 1119.04 \\
\hline 15 & Date + Stocking rate + Crop $2+$ Forest $5+$ Grassland 2 & 6 & 4.64 & 0.02 & 1119.16 \\
\hline 16 & Date + Field use & 7 & 13.25 & 0.00 & 1125.77 \\
\hline 17 & Date + Field use + Forest 2 & 8 & 14.15 & 0.00 & 1124.66 \\
\hline 18 & Date + Field use + Grassland 10 & 8 & 14.31 & 0.00 & 1124.82 \\
\hline 19 & Date + Field use + Crop2 & 8 & 14.32 & 0.00 & 1124.83 \\
\hline 20 & Date + Field use + Forest 5 & 8 & 15.08 & 0.00 & 1125.59 \\
\hline 21 & Date + Field use + Grassland 2 & 8 & 15.18 & 0.00 & 1125.69 \\
\hline 22 & Date + Field use + Forest $2+$ Forest 5 & 9 & 16.12 & 0.00 & 1124.63 \\
\hline 23 & Date + Field area + Forest $2+$ Forest 5 & 5 & 16.27 & 0.00 & 1132.80 \\
\hline 24 & Date + Field use + Grassland $2+$ Grassland 10 & 9 & 16.30 & 0.00 & 1124.80 \\
\hline 25 & Date + Field use + Crop $2+$ Forest $2+$ Grassland 10 & 10 & 17.07 & 0.00 & 1123.57 \\
\hline 26 & Date + Field use + Crop2 + Forest 2 + Grassland 2 & 10 & 17.89 & 0.00 & 1124.38 \\
\hline 27 & Date + Field area + Forest 5 & 4 & 19.15 & 0.00 & 1137.69 \\
\hline 28 & $\begin{array}{l}\text { Date }+ \text { Field area }+ \text { Crop } 2+\text { Forest } 2+\text { Forest } 5+\text { Grassland } 2+ \\
\text { Grassland } 10\end{array}$ & 8 & 19.40 & 0.00 & 1129.92 \\
\hline 29 & Date + Field area + Grassland 2 & 4 & 20.05 & 0.00 & 1138.59 \\
\hline 30 & Date + Region & 4 & 20.60 & 0.00 & 1139.14 \\
\hline 31 & Date + Crop $2+$ GrassFor $2+$ GrassFor $10+$ Forest $2+$ Forest 5 & 7 & 20.70 & 0.00 & 1133.22 \\
\hline 32 & $\begin{array}{l}\text { Date }+ \text { Field use }+ \text { Crop } 2+\text { Forest } 2+\text { Forest } 5+\text { Grassland } 2+ \\
\text { Grassland } 10\end{array}$ & 12 & 20.73 & 0.00 & 1123.21 \\
\hline 33 & Date + Forest 5 & 3 & 20.78 & 0.00 & 1141.32 \\
\hline 34 & Date + Field area + Grassland $2+$ Grassland 10 & 5 & 20.99 & 0.00 & 1137.52 \\
\hline
\end{tabular}




\begin{tabular}{llllll}
35 & Date + Grassland2 & 3 & 22.24 & 0.00 & 1142.78 \\
36 & Date + Field area + Crop2 + Forest2 + Grassland2 & 6 & 24.02 & 0.00 & 1138.54 \\
37 & Date + Crop250 & 3 & 24.18 & 0.00 & 1144.72 \\
38 & Region & 3 & 26.33 & 0.00 & 1146.87 \\
39 & Date & 2 & 27.57 & 0.00 & 1150.11 \\
40 & Date + Field area + Grassland10 & 4 & 27.68 & 0.00 & 1146.21 \\
41 & Date + Field area & 3 & 28.01 & 0.00 & 1148.55 \\
42 & Date + Grassland250 & $1 \dagger \dagger$ & 28.26 & 0.00 & 1148.80 \\
43 & Date + Grassland10 & 3 & 28.58 & 0.00 & 1149.12 \\
44 & Date + Water250 & 3 & 28.92 & 0.00 & 1149.46 \\
45 & Date + Forest2 & 3 & 29.00 & 0.00 & 1149.54 \\
46 & Date + Crop2 & 3 & 29.16 & 0.00 & 1149.70 \\
47 & Date + Forest250 $\$ \S$ & 3 & 29.34 & 0.00 & 1149.88 \\
48 & Date + Distance to forest edge & 3 & 29.38 & 0.00 & 1149.92 \\
49 & Date + Shrubland250 III & 3 & 29.47 & 0.00 & 1150.01 \\
50 & Date + Field area + Crop2 + Forest2 + Grassland10 & 6 & 29.48 & 0.00 & 1144.01 \\
51 & Date + Field area + Forest2 & 4 & 29.62 & 0.00 & 1148.16 \\
52 & Date + Field area + Crop2 & 4 & 29.98 & 0.00 & 1148.52 \\
53 & Date + Grassland250 + Forest250 + Crop250 + Shrubland250 & 7 & 31.49 & 0.00 & 1144.01 \\
+ Water250 & & & & \\
\hline
\end{tabular}

\footnotetext{
${ }^{\dagger}$ Number of parameters in the model.

\$Difference in AICc values compared to the best-supported model. AICc $=1126.55$ for the best supported model.

${ }^{\S}$ Model deviance.

INumber cattle $\times$ days grazed/area grazed.

II $\%$ forest within $2 \mathrm{~km}$ buffer around each nest.

\# \% forest within $5 \mathrm{~km}$ buffer around each nest.

$\dagger \%$ pasture, forage, and grassland within $2 \mathrm{~km}$ buffer around each nest.

林\% pasture, forage, and grassland within $10 \mathrm{~km}$ buffer around each nest.

$\$ \S \%$ crop within $2 \mathrm{~km}$ buffer around each nest.

I I grazed pasture (rotational and continuous), un-grazed pasture, hayfield, fallow field, restored grassland.

IIII Carden, Dufferin, and Renfrew region.

\#\# cropland within a $250 \mathrm{~m}$ buffer around each nest.

i† \% pasture, forage, and grassland within a $250 \mathrm{~m}$ buffer around each nest.

to\% $\%$ water within a $250 \mathrm{~m}$ buffer around each nest.

$\$ \$ \%$ forest within a $250 \mathrm{~m}$ buffer around each nest.

1I $\%$ shrubland within a $250 \mathrm{~m}$ buffer around each nest.

* Indicates best-supported model.
} 